Article

\title{
Enhancing the Quality of Total Mixed Ration Containing Cottonseed or Rapeseed Meal by Optimization of Fermentation Conditions
}

\author{
Hassan Ali Yusuf ${ }^{1,2} \mathbb{D}$, Minyu Piao ${ }^{1}$, Tao Ma ${ }^{1}\left(\mathbb{D}\right.$, Ruiying Huo ${ }^{1}$ and Yan Tu ${ }^{1, *(D)}$ \\ 1 Institute of Feed Research of Chinese Academy of Agricultural Sciences, Key Laboratory of Feed \\ Biotechnology of the Ministry of Agriculture and Rural Affairs, Beijing 100081, China; \\ Hassanagri99@gmail.com (H.A.Y.); tmpark729@126.com (M.P.); matao@caas.cn (T.M.); \\ huoruiying@caas.cn (R.H.) \\ 2 Faculty of Veterinary Medicine and Animal Husbandry, Somali National University, \\ Mogadishu P.O. Box 15, Somalia \\ * Correspondence: tuyan@caas.cn; Tel.: +86-10-8210-6090
}

Citation: Yusuf, H.A.; Piao, M.; Ma, T.; Huo, R.; Tu, Y. Enhancing the Quality of Total Mixed Ration Containing Cottonseed or Rapeseed Meal by Optimization of Fermentation Conditions. Fermentation 2021, 7, 234. https:// doi.org/10.3390/fermentation7040234

Academic Editor: Thaddeus Ezeji

Received: 19 September 2021

Accepted: 15 October 2021

Published: 19 October 2021

Publisher's Note: MDPI stays neutral with regard to jurisdictional claims in published maps and institutional affiliations.

Copyright: (c) 2021 by the authors. Licensee MDPI, Basel, Switzerland. This article is an open access article distributed under the terms and conditions of the Creative Commons Attribution (CC BY) license (https:// creativecommons.org/licenses/by/ $4.0 /)$.

\begin{abstract}
Cottonseed meal (CSM) and rapeseed meal (RSM) are protein sources in livestock feed. However, the applications of both ingredients are limited in diets due to the existence of antinutritional factors such as free gossypol and glucosinolate. The aim of this study was to determine the optimal fermentation conditions for reducing anti-nutritional factors and increasing the nutritional value of fermented total mixed rations containing cottonseed or rapeseed meal. An orthogonal design L9 $\left(3^{4}\right)$ was performed to optimize the fermentation conditions, including fermentation time, temperature, moisture content and microbial strain. Optimum fermentation conditions were performed using different fermentation times $(48,60,72 \mathrm{~h})$, fermentation temperatures $\left(28{ }^{\circ} \mathrm{C}\right.$, $\left.32{ }^{\circ} \mathrm{C}, 36{ }^{\circ} \mathrm{C}\right)$, moisture content $(40 \%, 50 \%, 60 \%)$ and microbial inoculations ( 1 = Bacillus clausii with $1 \times 10^{9} \mathrm{CFU} / \mathrm{kg}$ DM for CSM or $1 \times 10^{10} \mathrm{CFU} / \mathrm{kg}$ DM for RSM; 2 = Saccharomyces cariocanus with $5 \times 10^{9} \mathrm{CFU} / \mathrm{kg}$ DM; 3 = mixed strain (B. clausii:S. cariocanus ratio 1:1). The results show that the concentration of free gossypol content was reduced $(p<0.05)$, while the crude protein content was increased $(p<0.05)$ in CSM through optimum fermentation conditions: time $60 \mathrm{~h}$; temperature $32{ }^{\circ} \mathrm{C}$; moisture content $50 \%$ and inoculated with B. clausii $\left(1 \times 10^{9} \mathrm{CFU} / \mathrm{kg} \mathrm{DM}\right)$ as well as S. cariocanus $\left(5 \times 10^{9} \mathrm{CFU} / \mathrm{kg} \mathrm{DM}\right)$. Likewise, the concentration of glucosinolate was lowered $(p<0.05)$ and the crude protein was increased $(p<0.05)$ in RSM through optimum fermentation conditions: time $60 \mathrm{~h}$; temperature $28^{\circ} \mathrm{C}$; moisture $50 \%$ and inoculated with $B$. clausii $\left(1 \times 10^{10} \mathrm{CFU} / \mathrm{kg} \mathrm{DM}\right)$ as well as S. cariocanus $\left(5 \times 10^{9} \mathrm{CFU} / \mathrm{kg} \mathrm{DM}\right)$. Our findings indicate that the optimal fermentation conditions of total mixed rations with cottonseed meal or rapeseed meal enhance the nutritional value, thereby making them viable and usable feedstuffs for potential use in livestock industries.
\end{abstract}

Keywords: cottonseed meal; rapeseed meal; total mixed ration; optimum fermentation conditions; orthogonal design

\section{Introduction}

A growing demand for protein in the feed sector requires substituting other protein sources. As a result, interest in animal nutrition research for alternative plant proteins to replace soybean meal (SBM) has increased. We are interested in cottonseed meal (CSM) and rapeseed meal (RSM) since they are less expensive and more readily available locally (on a protein basis).

CSM is a by-product of cottonseed oil production that contains between $34-40 \%$ crude protein $(\mathrm{CP}), 11 \%$ crude fiber $(\mathrm{CF})$, vitamin $\mathrm{B}$, and organic phosphorus [1]. However, the use of CSM in animal diets is limited due to the presence of free gossypol (FG), a toxic pigment that may have a detrimental effect on the growth, reproduction and digestive 
development of animals, as well as resulting in internal organ abnormalities [2,3]. RSM is also a by-product of oil manufacture in large quantities. It contains high levels of protein and has a well-balanced amino acid profile [4,5], making it appropriate for use in livestock feed. Nevertheless, its meal contains glucosinolates $[6,7]$ and other anti-nutrient factors that could poison the animal and impair development performance $[8,9]$. Therefore, the use of RSM in livestock diets is limited.

Different approaches for CSM and RSM detoxifying have been formed, including biological $[10,11]$, chemical $[12,13]$ and physical $[14,15]$ detoxification. However, chemical and physical detoxification have drawbacks such as high expense, environmental problems and huge nutrient loss. In contrast, microbial fermentation is the optimal solution for detoxification since microorganisms' rapid growth could release complex enzymes that degrade the meal's toxic substances. Microorganism-mediated fermentation is an alternative method for removing anti-nutritional components of feed while increasing their nutritional content [16]. Additionally, microbial fermentation is the best processing approach since it substantially improves animal performance and health [17,18].

Bacillus clausii is a Gram-positive spore-forming microorganism that, when administered in sufficient amounts, confers health advantages on the host [19]. Yeast is widespread and is easily cultured in large quantities [20]. Saccharomycetes have been widely used to reduce the anti-nutritional factor content of diets [21]. Furthermore, yeast has been shown to increase the crude protein and mineral content of plant-based meals [22]. Although $S$. cerevisiae has been the potential approach for improving animal performance over the last two decades $[23,24]$, a recent study showed that $S$. cerevisiae is limited to creating cell biomass during aerated glucose fermentation. S. cerevisiae ferments alcohol rather than producing biomass when grown in aerobic conditions [25]. This restricts animal access to beneficial yeast biomasses such as protein, essential amino acids and vitamins. As a result, it is vital to expand the research field and strengthen the investigation into additional yeast strains. However, little information is available on optimizing fermented total mixed rations with CSM or RSM using B. clausii or S. cariocanus strains. This study aimed to optimize the fermentation conditions of fermented total mixed rations containing cottonseed or rapeseed meal using B. clausii or S. cariocanus to reduce the content of anti-nutritional factors and to determine their nutritional value.

\section{Materials and Methods}

\subsection{Experiment Time and Place}

This experiment was conducted from July 2020 to April 2021 at the Institute of Feed Research, Chinese Academy of Agricultural Sciences, Beijing 100081, China.

\subsection{Experimental Materials}

B. clausii with $1 \times 10^{9} \mathrm{CFU} / \mathrm{kg}$ DM or $1 \times 10^{10} \mathrm{CFU} / \mathrm{kg}$ DM and S. cariocanus with $5 \times 10^{9} \mathrm{CFU} / \mathrm{kg}$ DM used in this study were purchased from a local company (Gaotang Huanong Bioengineering Co. Ltd., Liaocheng, Shandong, China). The CSM ration and RSM ration used as the fermentation substrate were collected from a local feed manufacturer (Dadi Feed Company, Chengdu, Sichuang, China).

\subsection{Preparation and Formulation of TMR with CSM/RSM}

The formulation of TMR was mixed with CSM/RSM, corn, wheat bran, whole corn silage, corn stalk, urea, fat powder, and a premixed supplement. Total mixed ration with CSM or RSM was used as the fermentation substrate. TMR with CSM/RSM containing $200 \mathrm{~g}$ was mixed thoroughly according to a method described in [26].

\subsection{Design and Optimization of the Fermentation Conditions}

The orthogonal experiment design ( 4 factors $\times 3$ levels) was used to obtain the optimum fermentation time, temperature, moisture content and microbial strain (Table 1). Experiments were conducted in plastic bags containing $200 \mathrm{~g}$ TMR with CSM/RSM that 
was inoculated with B. clausii with $1 \times 10^{9} \mathrm{CFU} / \mathrm{kg}$ DM for CSM or $1 \times 10^{10} \mathrm{CFU} / \mathrm{kg} \mathrm{DM}$ for RSM, S. cariocanus with $5 \times 10^{9} \mathrm{CFU} / \mathrm{kg}$ DM and mixed strain B. clausii and S. cariocanus of ratio 1:1 throughout solid-state fermentation in three levels. Fermentation was performed using different fermentation periods $(48,60,72 \mathrm{~h})$, fermentation temperatures $\left(28^{\circ} \mathrm{C}, 32{ }^{\circ} \mathrm{C}\right.$, $\left.36^{\circ} \mathrm{C}\right)$, moisture content $(40 \%, 50 \%, 60 \%)$ and microbial inoculation levels $(1,2,3)$ according to a previously described approach [27]. The incubator settings controlled the fermentation period and temperature, which were maintained throughout the incubation period.

Table 1. Factors and levels selected for optimum fermentation conditions of orthogonal design.

\begin{tabular}{ccccc}
\hline \multirow{2}{*}{ Levels } & \multicolumn{3}{c}{ Factors } \\
\cline { 2 - 4 } & Fermentation Time (A) (h) & Fermentation Temperature (B) $\left({ }^{\circ} \mathbf{C}\right)$ & Moisture Content (C) (g/100g) & Microbial Strain (D) $\mathbf{1}^{\mathbf{2}}$ \\
\hline 1 & 48 & 28 & 40 \\
2 & 60 & 32 & 50 & 60 \\
3 & 72 & 36 & 2 & 3 \\
\hline
\end{tabular}

${ }^{1}$ Symbols 1, 2, and 3 of factor D; $1=$ Bacillus clausii at $1 \times 10^{9} \mathrm{CFU} / \mathrm{kg}$ DM for total mixed ration with CSM or $1 \times 10^{10} \mathrm{CFU} / \mathrm{kg}$ DM for total mixed ration with RSM; $2=$ Saccharomyces cariocanus at $5 \times 10^{9} \mathrm{CFU} / \mathrm{kg}$ DM for the total mixed rations; $3=$ mixed strain B. clausii:S. cariocanu at ratio 1:1 for total mixed rations. The arrangements of columns A, B, C and D were decided by orthogonal design for 4 (factor) $\times 3$ (levels).

The influence of fermentation time, fermentation temperature, moisture content and microbial strain on chemical composition and anti-nutritional factors (free gossypol, glucosinolate degradation) were evaluated. Nine different fermentation treatments were performed, as shown in Table 2. Each run was carried out in triplicate.

Table 2. Scheme of orthogonal L9 $\left(3^{4}\right)$ design for optimum fermentation conditions.

\begin{tabular}{|c|c|c|c|c|}
\hline \multirow{2}{*}{ Run } & \multicolumn{4}{|c|}{ Factors } \\
\hline & Fermentation Time (A) (h) & Fermentation Temperature (B) $\left({ }^{\circ} \mathrm{C}\right)$ & Moisture Content (C) (g/100g) & Microbial Strain (D) ${ }^{1}$ \\
\hline 1 & 48 & 28 & 40 & 1 \\
\hline 2 & 48 & 32 & 50 & 2 \\
\hline 3 & 48 & 36 & 60 & 3 \\
\hline 4 & 60 & 28 & 50 & 3 \\
\hline 5 & 60 & 32 & 60 & 1 \\
\hline 6 & 60 & 36 & 40 & 2 \\
\hline 7 & 72 & 28 & 60 & 2 \\
\hline 8 & 72 & 32 & 40 & 3 \\
\hline 9 & 72 & 36 & 50 & 1 \\
\hline
\end{tabular}

${ }^{1}$ Symbols 1,2 , and 3 of factor D; $1=$ Bacillus clausii at $1 \times 10^{9} \mathrm{CFU} / \mathrm{kg}$ DM for total mixed ration with CSM or $1 \times 10^{10} \mathrm{CFU} / \mathrm{kg}$ DM for total mixed ration with RSM; $2=$ Saccharomyces cariocanus at $5 \times 10^{9} \mathrm{CFU} / \mathrm{kg}$ DM for the total mixed rations; $3=$ mixed strain B. clausii:S. cariocanu at ratio 1:1 for total mixed rations. The arrangements of column A, B, C and D were decided by orthogonal design for 4 (factor) $\times 9$ (run number).

\subsection{Measurements}

\subsubsection{Chemical Composition}

After fermentation, TMR with CSM or RSM samples were dried at $65^{\circ} \mathrm{C}$ for $48 \mathrm{~h}$, ground and passed through a 1-mesh sieve. Samples were ground to pass through a 1-mm sieve size for analysis of dry matter (DM), crude protein (CP) and ether extract (EE) according to AOAC [28]. According to Van Soest et al. [29], neutral detergent fiber (NDF) and acid detergent fiber (ADF) were determined.

\subsubsection{Analysis of Anti-Nutritional Factors}

The free gossypol was determined using the official method of the American Oil Chemists Society [30]. The presence of 3-amino-1-propanol determined free gossypol, a mixture of isopropyl alcohol and n-hexane was used to extract free gossypol, and aniline was used to convert gossypol to aniline cotton phenol. The colorimetric determination was carried out at the maximum absorption of the spectrophotometer at the wavelength of $440 \mathrm{~nm}$. Two grams of the TMR with CSM sample was put in a $250 \mathrm{~mL}$ Erlenmeyer flask 
with a stopper, 20 glass beads and a pipette. The tube was filled with $50 \mathrm{~mL}$ of solvent, then the bottle was closed, put in the shaker and was oscillated for $1 \mathrm{~h}$. A dry filter was used and was then covered with funnel glass to reduce the solvent volatilization. The first few drops of the filtrate were discarded, and the remainder was collected using a $100 \mathrm{~mL}$ Erlenmeyer flask with a stopper.

Calculation Formula (Equation (1)):

$$
\mathrm{X}=\frac{\mathrm{A} \times 1250 \times 1000}{\mathrm{a} \times \mathrm{m} \times \mathrm{V}}=\frac{\mathrm{A} \times 1.25}{\mathrm{amV}} \times 10^{6}
$$

In the formula:

$\mathrm{X}=$ free gossypol content, $\mathrm{mg} / \mathrm{kg}$;

$\mathrm{A}=$ absorbance;

$\mathrm{M}=$ sample quality, $\mathrm{g}$;

$\mathrm{V}=$ the volume of filtrate for determination, $\mathrm{mL}$;

$\mathrm{a}=$ mass absorption coefficient, free gossypol is $62.5 \mathrm{~cm}^{-1} \mathrm{~g}^{-1} \mathrm{~L}$.

Correspondingly, glucosinolates of the TMR with RSM were determined using paladium chloride [31]. Briefly, $0.2 \mathrm{~g}$ of TMR with rapeseed meal was powdered in a mortar and added to a graduated test tube containing $10 \mathrm{~mL}$ boiling water. The mixtures were thoroughly shaken and heated for $30 \mathrm{~min}$ in a water bath before being diluted to $10 \mathrm{~mL}$ Following centrifugation, $2 \mathrm{~mL}$ of TMR with rapeseed meal extract suspension was pipetted to a graduated tube containing $4 \mathrm{~mL}$ of $0.15 \%$ sodium carboxymethyl cellulose and shaken well. Then, $2 \mathrm{~mL}$ of $8 \mathrm{mmol} / \mathrm{L}$ palladium chloride color was added. After vigorous stirring, the mixed solutions were kept at $22 \pm 3{ }^{\circ} \mathrm{C}$ for $2 \mathrm{~h}$. The absorption at $540 \mathrm{~nm}$ (A) was determined using sodium carboxymethyl cellulose as the reference material and a blank solution as the standard solution. The glucosinolate content was determined using absorbance A, proportional to the glucosinolate content as ascertained by the standard curve. Standard curve: $A=K x+b$.

$$
\text { Glucosinolate content }(X)=(A-b) / k
$$

$X=$ glucosinolate content; $(\mu \mathrm{mol} / \mathrm{g})$

$\mathrm{A}=$ absorbance value;

$\mathrm{K}$ and $\mathrm{b}=$ fixed values.

\subsection{Statistical Analysis}

Data were analyzed using one-way analysis of variance (ANOVA) using the general linear model (GLM) procedure of SAS software (version 9.4, SAS Institute, Cary, NC, USA). The significance of differences between mean values was assessed using Tukey's multiple comparisons to determine the statistical difference between means. Differences among treatment groups were considered significant if $p<0.05$.

\section{Results}

\subsection{Effect of Fermentation Conditions on Chemical Compositions of TMR with CSM or RSM}

As shown in Table 3, there were significant differences $(p<0.05)$ in the effects of time and temperature factor levels on CP. However, there was no significant difference in the effect of moisture and microbial strain factor levels on CP $(p>0.05)$. Thus, level two $\left(32{ }^{\circ} \mathrm{C}\right)$ fermentation temperature significantly increased $\mathrm{CP}$, followed by fermentation time, moisture content and microbial strain.

Similarly, as shown in Table 4, factor levels of fermentation time, fermentation temperature, moisture content and microbial strain had a significantly different effect on increasing crude protein $(p<0.05)$. The fermentation temperature level one $\left(28^{\circ} \mathrm{C}\right)$ had the greatest impact, followed by moisture content, microbial strain and fermentation time. Through the combined analyses, the composition of A3B1C2D3 was the best, i.e., the best composition of optimum fermentation conditions was fermentation time $72 \mathrm{~h}$, fermentation temper- 
ature $28^{\circ} \mathrm{C}$, moisture content $50 \%$ and mixed microbial strain (B. clausii with $1 \times 10^{9}: \mathrm{S}$. cariocanus with $5 \times 10^{9} \mathrm{CFU} / \mathrm{kg}$ DM for ratio 1:1).

Table 3. Effects of different factor levels on CP of TMR with CSM.

\begin{tabular}{ccccc}
\hline Level & Fermentation Time (A) & Fermentation Temperature (B) & Moisture Content (C) & Microbial Strain (D) \\
\hline 1 & $14.48^{\mathrm{b}}$ & $14.58^{\mathrm{b}}$ & 14.68 & 14.66 \\
2 & $14.69^{\mathrm{ab}}$ & $15.07^{\mathrm{a}}$ & 14.52 & 14.57 \\
3 & $14.72^{\mathrm{a}}$ & $14.25^{\mathrm{c}}$ & 14.69 & 14.67 \\
Delta & 0.25 & 0.83 & 0.17 & 0.10 \\
Rank & 2 & 1 & 3 & 4 \\
$p$-value & 0.022 & $<0.001$ & 0.121 & 0.454 \\
\hline
\end{tabular}

a,b,c Means in the same column with different superscripts differed $(p<0.05)$. Delta: difference between largest to smallest numbers in the column. Rank: based on the outcome of delta result as ranking order 1, 2, 3 and 4. CP, crude protein; TMR, total mixed ration; CSM, cottonseed meal.

Table 4. Effects of different factor levels on CP of TMR with RSM.

\begin{tabular}{ccccc}
\hline Level & Fermentation Time (A) & Fermentation Temperature (B) & Moisture Content (C) & Microbial Strain (D) \\
\hline 1 & $13.73^{\mathrm{b}}$ & $13.99^{\mathrm{a}}$ & $13.66^{\mathrm{b}}$ & $13.82^{\mathrm{a}}$ \\
2 & $13.81^{\mathrm{ab}}$ & $13.71^{\mathrm{b}}$ & $13.85^{\mathrm{a}}$ & $13.70^{\mathrm{b}}$ \\
3 & $13.82^{\mathrm{a}}$ & $13.65^{\mathrm{b}}$ & $13.84^{\mathrm{a}}$ & $13.83^{\mathrm{a}}$ \\
Delta & 0.09 & 0.34 & $0.19^{2}$ & 0.12 \\
Rank & 4 & 1 & 2 & 3 \\
$p$-value & 0.033 & $<0.001$ & $<0.001$ & 0.003 \\
\hline
\end{tabular}

${ }^{a}, \mathrm{~b}$ Means in the same column with different superscripts differed $(p<0.05)$. Delta: difference between largest to smallest numbers in the column. Rank: based on the outcome of delta result as ranking order 1, 2, 3 and 4. CP, crude protein; TMR, total mixed ration; RSM, rapeseed meal.

As indicated in Table 5, the degree of influence of each factor on the NDF of TMR with CSM was $\mathrm{C}>\mathrm{D}>\mathrm{B}>\mathrm{A}$. Likewise, there were significant differences $(p<0.05)$ among the various levels of each factor except factor (A). The fermentation temperature of level one showed the highest reduction in NDF compared with other levels. The moisture content of level one in factor $\mathrm{C}$ also displayed a lower reduction compared with other levels. In addition, the microbial strain of level one was a better reduction of NDF compared with others. According to these results, the optimal combination of the factors mentioned above were C1D1B1A2 (moisture content $40 \%$; a microbial strain of B. clausii with $1 \times 10^{9} \mathrm{CFU} / \mathrm{kg}$ $\mathrm{DM}$; fermentation temperature of $28^{\circ} \mathrm{C}$; fermentation time of $60 \mathrm{~h}$ ).

Table 5. Effects of different factor levels on NDF of TMR with CSM.

\begin{tabular}{ccccc}
\hline Level & Fermentation Time (A) & Fermentation Temperature (B) & Moisture Content (C) & Microbial Strain (D) \\
\hline 1 & 31.78 & $31.31^{\mathrm{b}}$ & $29.66^{\mathrm{c}}$ & $30.65^{\mathrm{b}}$ \\
2 & 31.62 & $32.04^{\mathrm{ab}}$ & $32.22^{\mathrm{b}}$ & $33.20^{\mathrm{a}}$ \\
3 & 32.54 & $32.58^{\mathrm{a}}$ & $34.06^{\mathrm{a}}$ & $32.09^{\mathrm{a}}$ \\
Delta & 0.91 & 1.27 & 4.41 & 2.55 \\
Rank & 4 & 3 & 1 & 2 \\
$p$-value & 0.149 & 0.048 & $<0.0001$ & 0.0002 \\
\hline
\end{tabular}

a,b,c Means in the same column with different superscripts differed $(p<0.05)$. Delta: difference between largest to smallest numbers in the column. Rank: based on the outcome of delta result as ranking order 1, 2, 3 and 4. NDF, neutral detergent fiber; TMR; total mixed ration; CSM, cottonseed meal.

Likewise, as presented in Table 6, factor levels of fermentation time, fermentation temperature and microbial strain did not significantly influence the optimum fermentation conditions for NDF $(p>0.05)$ of TMR with RSM. However, moisture content had a significant effect $(p<0.05)$ on NDF. Level one of moisture content $(40 \%)$ had a significantly better reduction on NDF than other levels $(p<0.05)$. 
Table 6. Effects of different factor levels on NDF of TMR with RSM.

\begin{tabular}{ccccc}
\hline Level & Fermentation Time (A) & Fermentation Temperature (B) & Moisture Content (C) & Microbial Strain (D) \\
\hline 1 & 29.50 & 31.52 & $28.87^{\mathrm{b}}$ & 30.64 \\
2 & 31.34 & 29.65 & $31.10^{\mathrm{a}}$ & 30.81 \\
3 & 31.17 & 30.84 & $32.04^{\mathrm{a}}$ & 30.56 \\
Delta & 1.84 & 1.87 & 3.18 & 0.25 \\
Rank & 3 & 2 & 1 & 4 \\
$p$-value & 0.083 & 0.114 & 0.005 & 0.956 \\
\hline
\end{tabular}

a,b Means in the same column with different superscripts differed $(p<0.05)$. Delta: difference between largest to smallest numbers in the column. Rank: based on the outcome of delta result as ranking order 1, 2, 3 and 4 . NDF, neutral detergent fiber; TMR; total mixed ration; RSM, rapeseed meal.

\subsection{Effect of Fermentation Conditions on Anti-Nutritional Factors}

As presented in Table 7, factor levels of fermentation time, temperature and moisture content had no significant effect on reducing free gossypol $(p>0.05)$. In contrast, the microbial strain had a significant effect $(p<0.01)$. However, levels two and three of microbial strain showed a better FG reduction than level one. This result indicates that the single strain of $S$. cariocanus with $5 \times 10^{9} \mathrm{CFU} / \mathrm{kg}$ DM or mixed strain (B. clausii with $1 \times 10^{9}:$ S. cariocanus with $5 \times 10^{9} \mathrm{CFU} / \mathrm{kg} \mathrm{DM}$ ) had the most influence on the optimum fermentation conditions of detoxification of free gossypol of fermented TMR with CSM.

Table 7. Optimal fermentations of FG of TMR with CSM.

\begin{tabular}{ccccc}
\hline Level & Fermentation Time (A) & Fermentation Temperature (B) & Moisture Content (C) & Microbial Strain (D) \\
\hline 1 & 68.30 & 64.14 & 65.50 & $74.34^{\mathrm{a}}$ \\
2 & 65.03 & 69.34 & 67.65 & $61.75^{\mathrm{b}}$ \\
3 & 67.64 & 67.47 & 67.80 & $64.86^{\mathrm{b}}$ \\
Delta & 3.27 & 5.20 & 2.30 & 12.59 \\
Rank & 3 & 2 & 4 & 1 \\
-value & 0.2731 & 0.0628 & 0.4753 & $<0.0001$ \\
\hline
\end{tabular}

a,b Means in the same column with different superscripts differed $(p<0.05)$. Delta: difference between largest to smallest numbers in the column. Rank: based on the outcome of delta result as ranking order 1, 2, 3 and 4. FG, free gossypol; TMR; total mixed ration; CSM, cottonseed meal.

Based on the degree order of rank, as displayed in Table 8, the effect of the factors on the glucosinolate decreased in the following order: initial moisture content $(\mathrm{C})$, fermentation temperature (B), microbial strain (D) and fermentation time (A). Therefore, based on the magnitude, the optimal combination was A3B2C3D3.

Table 8. Effects of different factor levels on glucosinolate of TMR with RSM.

\begin{tabular}{ccccc}
\hline Level & Fermentation Time (A) & Fermentation Temperature (B) & Moisture Content (C) & Microbial Strain (D) \\
\hline 1 & $4.320^{\mathrm{a}}$ & $4.716^{\mathrm{a}}$ & $5.730^{\mathrm{a}}$ & $4.261^{\mathrm{a}}$ \\
2 & $3.872^{\mathrm{ab}}$ & $3.079^{\mathrm{b}}$ & $3.559^{\mathrm{b}}$ & $4.058^{\mathrm{a}}$ \\
3 & $3.245^{\mathrm{b}}$ & $3.642^{\mathrm{b}}$ & $2.147^{\mathrm{c}}$ & $3.118^{\mathrm{b}}$ \\
Delta & $1.075^{\mathrm{b}}$ & 1.637 & 3.583 & 1.144 \\
Rank & 4 & 2 & 1 & 3 \\
$p$-value & 0.002 & $<0.001$ & $<0.001$ & 0.001 \\
\hline
\end{tabular}

$\mathrm{a}, \mathrm{b}, \mathrm{c}$ Means in the same column with different superscripts differed $(p<0.05)$. Delta: difference between largest to smallest numbers in the column. Rank: based on the outcome of delta result as ranking order 1, 2, 3 and 4. GL, glucosinolate, TMR; total mixed ration; RSM, rapeseed meal.

\subsection{An Optimum Combination of Four-Factor Orthogonal Tests of TMR with CSM/RSM}

The combination of four factors of orthogonal tests is presented in Table 9. There was a significant difference $(p<0.01)$ among the nine runs of experiments, as shown in Table 9. This indicates that the optimal combination of chemical compositions and anti- 
nutritional factors of run 8 was better than other runs. According to these results, the optimal combination of the factors mentioned above was A3B2C1D3. However, we have selected A2B2C2D3 (time $60 \mathrm{~h}$; temperature $32{ }^{\circ} \mathrm{C}$; moisture $50 \%$ and mixed microbial strain (B. clausii with $1 \times 10^{9}:$ S. cariocanus with $5 \times 10^{9} \mathrm{CFU} / \mathrm{kg}$ DM for ratio of $1: 1$ ) for optimum fermentation conditions of the subsequent experiment of TMR with CSM since there was no statistical significance between levels two and three (A2 \& A3) in Tables 3, 5 and 7. In addition, the effect of factor level of moisture content on other parameters such as $\mathrm{CP}$ and FG of fermented TMR with CSM were not significant except NDF under the moisture content of factor levels. Thus, level one of $40 \%$ showed the highest reduction of NDF, but $\mathrm{NDF}$ that is too low is not wide enough for the diet; thus, level two (32.22\% of NDF) had a moisture content of 50\%, and was given attention for subsequent experiments.

Table 9. Orthogonal results of fermentation test with multi factors of TMR with CSM.

\begin{tabular}{|c|c|c|c|c|c|c|c|}
\hline \multirow{3}{*}{ Run } & \multirow{3}{*}{ Time (A) } & \multirow{3}{*}{ Temperature (B) } & \multirow{3}{*}{ Moisture (C) } & \multirow{3}{*}{ Microbial Strain (D) } & \multicolumn{3}{|c|}{ Result } \\
\hline & & & & & \multicolumn{2}{|c|}{ Chemical Composition } & \multirow{2}{*}{$\begin{array}{c}\text { Anti-Nutritional } \\
\text { FG }\end{array}$} \\
\hline & & & & & $\mathrm{CP}$ & NDF & \\
\hline 1 & 1 & 1 & 1 & 1 & $14.50^{\mathrm{ab}} \pm 0.480$ & $27.46^{\mathrm{a}} \pm 0.354$ & $71.32^{\mathrm{ab}} \pm 3.143$ \\
\hline 2 & 1 & 2 & 2 & 2 & $14.74^{b c} \pm 0.085$ & $33.31^{\text {cde }} \pm 0.303$ & $66.09 \mathrm{ab} \pm 0.376$ \\
\hline 3 & 1 & 3 & 3 & 3 & $14.19^{\mathrm{a}} \pm 0.040$ & $34.58^{\text {de }} \pm 1.412$ & $67.48^{\mathrm{ab}} \pm 4.898$ \\
\hline 4 & 2 & 1 & 2 & 3 & $14.57^{\mathrm{ab}} \pm 0.080$ & $31.31^{b c} \pm 0.597$ & $60.73^{a} \pm 5.406$ \\
\hline 5 & 2 & 2 & 3 & 1 & $15.21^{\mathrm{c}} \pm 0.157$ & $32.43^{\text {bcde }} \pm 1.628$ & $75.55^{b} \pm 2.463$ \\
\hline 6 & 2 & 3 & 1 & 2 & $14.30^{\mathrm{ab}} \pm 0.070$ & $31.12^{b c} \pm 0.731$ & $58.79^{\mathrm{a}} \pm 5.007$ \\
\hline 7 & 3 & 1 & 3 & 2 & $14.66^{\mathrm{ab}} \pm 0.021$ & $35.17^{\text {e }} \pm 0.920$ & $60.38^{a} \pm 3.650$ \\
\hline 8 & 3 & 2 & 1 & 3 & $15.26^{\mathrm{c}} \pm 0.151$ & $30.39^{\mathrm{b}} \pm 1.324$ & $66.38^{\mathrm{ab}} \pm 4.545$ \\
\hline 9 & 3 & 3 & 2 & 1 & $14.25^{\mathrm{ab}} \pm 0.076$ & $32.05^{\mathrm{bcd}} \pm 0.872$ & $76.14^{\mathrm{b}} \pm 6.719$ \\
\hline SEM & & & & & 0.078 & 0.458 & 1.376 \\
\hline$p$-value & & & & & $<0.001$ & $<0.001$ & $<0.001$ \\
\hline
\end{tabular}

$\mathrm{a}, \mathrm{b}, \mathrm{c}, \mathrm{d}, \mathrm{e}$ Means in the same column with different superscripts differed $(p<0.05)$. The arrangements of columns A, B, C and D were decided by orthogonal design for 4 (factor) $\times 9$ (run number). CP, crude protein; NDF, neutral detergent fiber; FG, free gossypol; TMR; total mixed ration; CSM, cottonseed meal.

Nine runs of experiments were evaluated, and the experimental results of the orthogonal test were significantly different $(p<0.05)$ among the treatments as shown in Table 10. This demonstrates that the optimal fermentation conditions for chemical compositions and anti-nutritional factors of runs 4 and 7 had better results than other runs. According to these results, the optimal combination of the factors mentioned earlier in runs 4 and 7 were A2B1C2D3 and A3B1C3D2, respectively. However, we have selected A2B1C2D3 (time $60 \mathrm{~h}$; temperature $28{ }^{\circ} \mathrm{C}$; moisture $50 \%$ and mixed microbial strain (B. clausii with $1 \times 10^{9}$ :S. cariocanus with $5 \times 10^{9} \mathrm{CFU} / \mathrm{kg} \mathrm{DM}$ ) for optimum fermentation conditions of the subsequent experiment of TMR with RSM since there was no statistical significance difference between them.

Table 10. Orthogonal results of fermentation test with multi factors of TMR with RSM.

\begin{tabular}{|c|c|c|c|c|c|c|c|}
\hline \multirow{3}{*}{ Run } & \multirow{3}{*}{ Time (A) } & \multirow{3}{*}{ Temperature (B) } & \multirow{3}{*}{ Moisture (C) } & \multirow{3}{*}{ Microbial Strain (D) } & \multicolumn{3}{|c|}{ Result } \\
\hline & & & & & \multicolumn{2}{|c|}{ Chemical Composition } & \multirow{2}{*}{$\frac{\text { Anti-Nutritional }}{\text { GL }}$} \\
\hline & & & & & $\mathrm{CP}$ & NDF & \\
\hline 1 & 1 & 1 & 1 & 1 & $13.84^{\mathrm{bc}} \pm 0.061$ & $28.51^{\mathrm{ab}} \pm 2.555$ & $7.59^{d} \pm 0.416$ \\
\hline 2 & 1 & 2 & 2 & 2 & $13.65^{\mathrm{ab}} \pm 0.025$ & $29.05^{\mathrm{ab}} \pm 1.224$ & $3.58^{b} \pm 0.673$ \\
\hline 3 & 1 & 3 & 3 & 3 & $13.70^{b} \pm 0.076$ & $30.93^{\mathrm{ab}} \pm 2.134$ & $1.79^{\mathrm{a}} \pm 0.462$ \\
\hline 4 & 2 & 1 & 2 & 3 & $14.12^{\mathrm{d}} \pm 0.010$ & $32.51^{\mathrm{ab}} \pm 1.714$ & $3.83^{b} \pm 1.089$ \\
\hline 5 & 2 & 2 & 3 & 1 & $13.83^{\mathrm{bc}} \pm 0.095$ & $31.66^{\mathrm{ab}} \pm 1.137$ & $1.92^{\mathrm{a}} \pm 0.866$ \\
\hline 6 & 2 & 3 & 1 & 2 & $13.46^{\mathrm{a}} \pm 0.110$ & $29.85^{\mathrm{ab}} \pm 2.966$ & $5.86^{\mathrm{c}} \pm 0.282$ \\
\hline 7 & 3 & 1 & 3 & 2 & $14.00^{\mathrm{cd}} \pm 0.045$ & $33.53^{b} \pm 1.039$ & $2.73^{\mathrm{ab}} \pm 0.110$ \\
\hline 8 & 3 & 2 & 1 & 3 & $13.66^{\mathrm{ab}} \pm 0.035$ & $28.24^{\mathrm{a}} \pm 1.387$ & $3.73^{b} \pm 0.329$ \\
\hline 9 & 3 & 3 & 2 & 1 & $13.78^{b} \pm 0.031$ & $31.74^{\mathrm{ab}} \pm 0.852$ & $3.27^{\mathrm{ab}} \pm 0.704$ \\
\hline SEM & & & & & 0.038 & 0.449 & 0.353 \\
\hline$p$-value & & & & & $<0.001$ & $<0.02$ & $<0.001$ \\
\hline
\end{tabular}

a,b,c,d Means in the same column with different superscripts differed $(p<0.05)$. The arrangements of columns A, B, C and D were decided by orthogonal design for 4 (factor) $\times 9$ (run number). CP, crude protein; NDF, neutral detergent fiber; GL, glucosinolates, TMR; total mixed ration; RSM, rapeseed meal. 


\section{Discussion}

The purpose of this study was to determine the optimal fermentation conditions to reduce anti-nutritional factors in the fermented total mixed ration containing either cottonseed or rapeseed meal. Optimum selection and optimization of technical parameters such as the temperature, time, moisture content of the fermentation medium, and the inoculation strains are critical to improve the efficiency of solid-state fermentation [32].

In this study, protein enrichment was increased as the fermentation temperature slightly increased. The level two $\left(32^{\circ} \mathrm{C}\right)$ fermentation temperature (factor B) was the most significant one increasing the CP of fermented TMR with CSM. Similarly, the CP of fermented TMR with RSM increased when the fermentation temperature was at $28^{\circ} \mathrm{C}$. Proteins and enzymes are susceptible to denaturation when exposed to high temperatures. However, the beneficial effect of increased temperature on improved protein content can be associated with greater enzyme secretion by certain microbes [33,34]. Inoculated microbes enhanced the CP levels of both fermented TMR with CSM/RSM, and maintaining a steady temperature throughout fermentation was noted as necessary to keep the bacteria growing and active [35]. The optimal temperature for reducing the concentration of GL was $32^{\circ} \mathrm{C}$, indicating that this temperature is favorable for microbial growth in fermented TMR with rapeseed meal medium. The reduction percentages of GL in TMR with RSM were $83.31 \%$ and $80.26 \%$ at $32{ }^{\circ} \mathrm{C}$ and $36^{\circ} \mathrm{C}$, respectively. However, our result was consistent with a previous study showing that the degradation rate of GL increases to the highest value from $30{ }^{\circ} \mathrm{C}$ to $36^{\circ} \mathrm{C}$, and then decreases when further raising the temperature [26]. This may be due to the increased temperature having a detrimental influence on the metabolic activities of microorganisms, and numerous scientists have found that the metabolic activities of microorganisms become sluggish at lower temperatures [36]. Our research revealed that the temperature rise to $32{ }^{\circ} \mathrm{C}$ was optimum, above which the reduction of glucosinolates decreased. This may be due to the increase in fermentation temperature promoting microbes' growth and their activity in decreasing the amount of glucosinolates present in the fermented product.

Another significant element is the time needed for fermentation, which has been shown to increase the crude protein content in the fermented TMR with CSM/RSM. As the fermentation periods extended, the crude protein content increased. Our findings are consistent with a study showing that the degradation rate of glucosinolates increased rapidly from 24 to $72 \mathrm{~h}$, reaching a maximum of $83.67 \%$ after $72 \mathrm{~h}$ of fermentation [26]. Reduced fermentation time combined with good optimal fermentation is our priority because it can increase time efficiency and lower costs.

The moisture content is also important in protein enrichment during the solid-state fermentation [37]. The requirements of moisture content for yeast and bacteria are different. Low moisture content decreases the solubility of nutrients, thereby limiting microbial growth. However, high moisture content could reduce the porosity of substrates and promote material adhesion, which may affect temperature and oxygen transfer [38,39]. This study's optimum moisture contents were $40 \%$ and 50\% for TMR with CSM or RSM, respectively. The absorption of the substrate may be responsible for the difference in results. Correspondingly, our study showed that fermented TMR with rapeseed meals containing $50 \%$ and $60 \%$ moisture achieved the degradation rate of Gl at levels of $80.71 \%$ and $88.36 \%$, respectively. However, our study is higher than that reported by Shi et al. [40], who found that the substrate containing $60 \%$ moisture achieved the degradation rate of $\mathrm{Gl}$ at levels of $76.89 \%$ of RSC. Therefore, the optimal moisture content for the degradation rate of Gl appeared to be $50-60 \%$.

Conversely, the factor levels of moisture content affecting other parameters such as CP and FG of fermented TMR with CSM were not significant except NDF under the moisture content of factor levels; thus level one of $40 \%$ of moisture content showed the highest reduction in NDF, but NDF that is too low is not wide enough for the diet. Thus, level two of moisture content of 50\% showed a satisfying reduction in NDF (32.22\%), which can be utilized in the subsequent study. However, Ma et al. [41] reported that diets 
high in NFC/NDF increased microbial nitrogen (MN) and metabolizable $\mathrm{N}$, the ratio of metabolizable $\mathrm{N}$ to digestible protein or $\mathrm{N}$ intake in lambs, and decreased urinary $\mathrm{N}$ output. Similarly, incorporating protein sources into high-fiber feed might improve the utilization of these feeds by ruminants because of improved ruminal conditions [42].

In this study, we used single-strain (B. clausii or S. cariocanus) and mixed-strain (B. clausii:S. cariocanus at a 1:1 ratio) fermented TMR with CSM/RSM, which not only decreased the content of anti-nutritional factors but also enhanced the protein content. In the present study, mixed strains increased CP content (from $12.49 \%$ to $14.67 \%$ and from $11.65 \%$ to $13.83 \%$ ) through TMR optimization with CSM or RSM, respectively. Furthermore, fermented TMR with CSM/RSM enhanced the CP content, which agreed with the results found with fermented CSC [27], rapeseed meal [43] and fermentation of soy meal [44]. Similarly, crude protein increased from $49.8 \%$ to $51 \%$ when cottonseed meal was inoculated with B.s subtilis ST-141 and Saccharomycetes N5 [45]. An increase in CP content resulting from fermented TMR with CSM/RSM could be due to the optimum fermentation conditions that allow/make it suitable for synthesizing the microorganisms' proteins [43]. The increased CP level in fermented TMR with CSM/RSM is beneficial because it reduces other dietary protein sources and feed costs.

Cottonseed and rapeseed meals contain anti-nutritional factors that may disrupt nutrient availability, end up causing toxicity and impair animal performance [46]. Fermentation conditions such as time, temperature, moisture content and microbial strain must be considered to optimize FG and glucosinolate degradation with the least amount of nutrient loss possible. In the present study, factor levels such as time, temperature and moisture content did not significantly differ in FG degradation. At the same time, the mixed microbial strain showed a higher reduction of FG than with $B$. clausii, though the single- and mixed-strains were not significantly different. Similarly, the mixed strain of B. clausii and S. cariocanus, at a ratio of 1:1, showed the higher optimal reduction of glucosinolate. These results indicate that the fermentation of the mixed strain enhanced the reduction of $36.74 \%$ and $83.10 \%$ of FG and glucosinolate in TMR with CSM/RSM, respectively. Yeasts and bacterial strains can grow in synergy with one another, and this capability has led to their widespread use as co-cultures to improve the quality of unconventional feeds [47]. However, our study, in line with some other studies, has shown that mixed strains have a more practical effect on fermentation than a single strain [48]. Similar to that, our findings are consistent with prior studies showing that the degradation abilities of all the combined strains were better than a single strain for the degradation of glucosinolates after fermentation [49]. Likewise, our result is in line with the microorganisms of C. utilis and B. subtilis combined to ferment Moringa oleifera leaf meal, which reduced anti-nutritional compounds and increased the protein content [50]. As a result, combining multiple enzymes from yeast and bacteria is required to remove anti-nutritional elements from cottonseed or rapeseed meal. Anti-nutritional factors may be difficult to degrade when using solid-state fermentation with a single strain of microbe.

\section{Conclusions}

In this study, increase in $\mathrm{CP}$ and decrease in NDF as well as reduction in antinutritional factors were observed during fermentation of both TMRs containing CSM/RSM. Consequently, the optimal fermentation conditions of fermented TMR containing CSM were as follows: time $60 \mathrm{~h}$; temperature $32{ }^{\circ} \mathrm{C}$; moisture $50 \%$ and mixed microbial strain (B. clausii with $1 \times 10^{9}$ :S. cariocanus with $5 \times 10^{9} \mathrm{CFU} / \mathrm{kg} \mathrm{DM}$ ). Likewise, the optimal fermentation conditions of fermented TMR containing RSM were as follows: time $60 \mathrm{~h}$; temperature $28^{\circ} \mathrm{C}$; moisture $50 \%$ and mixed microbial strain (B. clausii with $1 \times 10^{10}$ :S. cariocanus with $5 \times 10^{9} \mathrm{CFU} / \mathrm{kg} \mathrm{DM}$ ). In addition, this research provides insight into the use of CSM or RSM in TMR that could potentially replace SBM in ruminant production. The results of these experiments should be evaluated in vivo to evaluate their effect on animal performance. 
Author Contributions: Conceptualization, H.A.Y., Y.T. and M.P.; methodology, H.A.Y., Y.T. and M.P.; formal analysis, H.A.Y., R.H. and T.M.; investigation, H.A.Y., R.H., M.P. and T.M.; writing-original draft preparation, H.A.Y.; writing-review and editing, H.A.Y., M.P. and T.M.; supervision, Y.T. All authors have read and agreed to the published version of the manuscript.

Funding: This study was funded by the Agricultural Sciences and Technology Innovation Program (CAAS-ASTIP-2017-FRI-04) and by the China Agriculture Research System of MOF and MARA.

Institutional Review Board Statement: Not applicable.

Informed Consent Statement: Not applicable.

Data Availability Statement: The data that support the findings of this study are available on request from the corresponding author.

Conflicts of Interest: The authors have declared no conflict of interest.

\section{References}

1. Zhang, Y.; Zhang, Z.; Dai, L.; Liu, Y.; Cheng, M.; Chen, L. Isolation and characterization of a novel gossypol-degrading bacteria Bacillus subtilis strain Rumen Bacillus Subtilis. Asian-Australas. J. Anim. Sci. 2018, 31, 63-70. [CrossRef]

2. Francis, G.; Makkar, H.P.; Becker, K. Antinutritional factors present in plant-derived alternate fish feed ingredients and their effects in fish. Aquaculture 2001, 199, 197-227. [CrossRef]

3. Robinson, P.; Getachew, G.; De Peters, E.; Calhoun, M. Influence of variety and storage for up to 22 days on nutrient composition and gossypol level of Pima cottonseed (Gossypium spp.). Anim. Feed Sci. Technol. 2001, 91, 149-156. [CrossRef]

4. Fan, X.; Tang, S.; Li, G.; Zhou, X. Non-invasive detection of protein content in several types of plant feed materials using a hybrid near infrared spectroscopy model. PLoS ONE 2016, 11, e0163145. [CrossRef]

5. Ivanova, P.; Kalaydzhiev, H.; Rustad, T.; Silva, C.L.; Chalova, V.I. Comparative biochemical profile of protein-rich products obtained from industrial rapeseed meal. Emir. J. Food Agric. 2017, 29, 170-178. [CrossRef]

6. Tripathi, M.; Mishra, A. Glucosinolates in animal nutrition: A review. Anim. Feed Sci. Technol. 2007, 132, 1-27. [CrossRef]

7. Verkerk, R.; Schreiner, M.; Krumbein, A.; Ciska, E.; Holst, B.; Rowland, I.; De Schrijver, R.; Hansen, M.; Gerhäuser, C.; Mithen, R. Glucosinolates in Brassica vegetables: The influence of the food supply chain on intake, bioavailability and human health. Mol. Nutr. Food Res. 2009, 53, S219. [CrossRef]

8. Jannathulla, R.; Dayal, J.S.; Vasanthakumar, D.; Ambasankar, K.; Muralidhar, M. Effect of fermentation methods on amino acids, fiber fractions and anti-nutritional factors in different plant protein sources and essential amino acid index for Penaeus vannamei Boone, 1931. Indian J. Fish. 2017, 64, 40-47. [CrossRef]

9. Liu, Y.-G.; Zhou, M.-Q.; Liu, M.-L. A survey of nutrients and toxic factors in commercial rapeseed meal in China and evaluation of detoxification by water extraction. Anim. Feed Sci. Technol. 1994, 45, 257-270. [CrossRef]

10. Brabban, A.; Edwards, C. Isolation of glucosinolate degrading microorganisms and their potential for reducing the glucosinolate content of rapemeal. FEMS Microbiol. Lett. 1994, 119, 83-88. [CrossRef]

11. Finnigan, T.A.; Lewis, M. Detoxification of alkaline extract of United Kingdom commercial rapeseed meal by diafiltration. Lebensm.-Wiss.+Technol. 1989, 22, 116-118.

12. Barrett, J.; Klopfenstein, C.; Leipold, H. Detoxification of rapeseed meal by extrusion with an added basic salt. Cereal Chem. 1997, 74, 168-170. [CrossRef]

13. Watts, E.S.; Rose, S.P.; Mackenzie, A.M.; Pirgozliev, V.R. The effects of supercritical carbon dioxide extraction and cold-pressed hexane extraction on the chemical composition and feeding value of rapeseed meal for broiler chickens. Arch. Anim. Nutr. 2020, 74, 57-71. [CrossRef]

14. Gu, X.; Dong, W.; He, Y. Detoxification of rapeseed meals by steam explosion. J. Am. Oil Chem. Soc. 2011, 88, 1831-1838. [CrossRef]

15. Haddad, J.; Allaf, K. Effect of Instantaneous Controlled Pressure Drop on the glucosinolate content of rapeseed. Int. J. Food Sci. Technol. 2007, 42, 799-803. [CrossRef]

16. Wang, Y.; Liu, J.; Wei, F.; Liu, X.; Yi, C.; Zhang, Y. Improvement of the nutritional value, sensory properties and bioavailability of rapeseed meal fermented with mixed microorganisms. LWT 2019, 112, 108238. [CrossRef]

17. Sun, H.; Tang, J.-W.; Yao, X.-H.; Wu, Y.-F.; Wang, X.; Feng, J. Improvement of the Nutritional Quality of Cottonseed Meal by Bacillus subtilis and the Addition of Papain. Int. J. Agric. Biol. 2012, 14, 563-568.

18. Wang, X.; Tang, J.-W.; Yao, X.-H.; Wu, Y.-F.; Sun, H.; Xu, Y.-X. Effect of Bacillus cereus Br on bacterial community and gossypol content during fermentation in cottonseed meal. Afr. J. Microbiol. Res. 2012, 6, 6537-6544. [CrossRef]

19. Urdaci, M.C.; Bressollier, P.; Pinchuk, I. Bacillus clausii probiotic strains: Antimicrobial and immunomodulatory activities. J. Clin. Gastroenterol. 2004, 38, S86-S90. [CrossRef]

20. Shurson, G. Yeast and yeast derivatives in feed additives and ingredients: Sources, characteristics, animal responses, and quantification methods. Anim. Feed Sci. Technol. 2018, 235, 60-76. [CrossRef]

21. Greiner, R.; Konietzny, U. Phytase for food application. Food Technol. Biotechnol. 2006, 44, 125-140. 
22. Plaipetch, P.; Yakupitiyage, A. Effect of replacing soybean meal with yeast-fermented canola meal on growth and nutrient retention of Nile tilapia, Oreochromis niloticus (Linnaeus 1758). Aquac. Res. 2014, 45, 1744-1753. [CrossRef]

23. Mohammed, S.F.; Mahmood, F.A.; Abas, E.R. A review on effects of yeast (Saccharomyces cerevisiae) as feed additives in ruminants performance. J. Entomol. Zool. Stud. 2018, 6, 629-635.

24. Stancheva, N.; Beev, G. Yeast cultures in ruminant nutrition. Bulg. J. Agric. Sci. 2007, 13, 357-374.

25. Dashko, S.; Zhou, N.; Compagno, C.; Piškur, J. Why, when, and how did yeast evolve alcoholic fermentation? FEMS Yeast Res. 2014, 14, 826-832. [CrossRef]

26. Zhang, Z.; Wen, M.; Chang, Y. Degradation of glucosinolates in rapeseed meal by Lactobacillus delbrueckii and Bacillus subtilis. Grain Oil Sci. Technol. 2020, 3, 70-76. [CrossRef]

27. Vellaichamy, M. Optimization of solid state fermentation process for gossypol detoxification in heat sterilized cotton seed cake by mixed fungal cultures. Int. J. Food Ferment. Technol. 2016, 6, 97-102. [CrossRef]

28. Association of Official Analytical Chemists; Horwitz, W. Official Methods of Analysis; Association of Official Analytical Chemists: Washington, DC, USA, 1975; Volume 222.

29. Van Soest, P.v.; Robertson, J.; Lewis, B. Methods for dietary fiber, neutral detergent fiber, and nonstarch polysaccharides in relation to animal nutrition. J. Dairy Sci. 1991, 74, 3583-3597. [CrossRef]

30. AOCS. Free and Total Gossypol Methods; Official and Tentative Methods of the AOCS: Champaign, IL, USA, 1999.

31. Wathelet, J.P.; Wagstaffe, P.J.; Biston, R.; Marlier, M.; Severin, M. Rapeseed reference materials for glucosinolate analysis. Z. Anal. Chem. 1988, 332, 689-693. [CrossRef]

32. Abu Yazid, N.; Barrena, R.; Komilis, D.; Sánchez, A. Solid-state fermentation as a novel paradigm for organic waste valorization: A review. Sustainability 2017, 9, 224. [CrossRef]

33. Abraham, J.; Gea, T.; Sánchez, A. Substitution of chemical dehairing by proteases from solid-state fermentation of hair wastes. J. Clean. Prod. 2014, 74, 191-198. [CrossRef]

34. Yazid, N.A.; Barrena, R.; Sánchez, A. Assessment of protease activity in hydrolysed extracts from SSF of hair waste by and indigenous consortium of microorganisms. Waste Manag. 2016, 49, 420-426. [CrossRef]

35. Alkhamis, T.; El-Khazali, R.; Kablan, M.; Alhusein, M. Heating of a biogas reactor using a solar energy system with temperature control unit. Sol. Energy 2000, 69, 239-247. [CrossRef]

36. Zhang, W.-J.; Xu, Z.-R.; Zhao, S.-H.; Jiang, J.-F.; Wang, Y.-B.; Yan, X.-H. Optimization of process parameters for reduction of gossypol levels in cottonseed meal by Candida tropicalis ZD-3 during solid substrate fermentation. Toxicon 2006, 48, 221-226. [CrossRef]

37. Orzua, M.C.; Mussatto, S.I.; Contreras-Esquivel, J.C.; Rodriguez, R.; de la Garza, H.; Teixeira, J.A.; Aguilar, C.N. Exploitation of agro industrial wastes as immobilization carrier for solid-state fermentation. Ind. Crop. Prod. 2009, 30, 24-27. [CrossRef]

38. Sadh, P.K.; Duhan, S.; Duhan, J.S. Agro-industrial wastes and their utilization using solid state fermentation: A review. Bioresour. Bioprocess. 2018, 5, 1-15. [CrossRef]

39. Sousa, D.; Venâncio, A.; Belo, I.; Salgado, J.M. Mediterranean agro-industrial wastes as valuable substrates for lignocellulolytic enzymes and protein production by solid-state fermentation. J. Sci. Food Agric. 2018, 98, 5248-5256. [CrossRef]

40. Shi, C.; He, J.; Yu, J.; Yu, B.; Huang, Z.; Mao, X.; Zheng, P.; Chen, D. Solid state fermentation of rapeseed cake with Aspergillus niger for degrading glucosinolates and upgrading nutritional value. J. Anim. Sci. Biotechnol. 2015, 6, 1-7. [CrossRef]

41. Ma, T.; Tu, Y.; Zhang, N.F.; Deng, K.D.; Diao, Q.Y. Effect of the Ratio of Non-fibrous Carbohydrates to Neutral Detergent Fiber and Protein Structure on Intake, Digestibility, Rumen Fermentation, and Nitrogen Metabolism in Lambs. Asian-Australas. J. Anim. Sci. 2015, 28, 1419-1426. [CrossRef]

42. Leng, R. Application of Biotechnology to Nutrition of Animals in Developing Countries; Etude FAO: Rome, Italy, 1993. (In French)

43. Hao, Y.; Wang, Z.; Zou, Y.; He, R.; Ju, X.; Yuan, J. Effect of static-state fermentation on volatile composition in rapeseed meal. J. Sci. Food Agric. 2020, 100, 2145-2152. [CrossRef]

44. Chen, L.; Madl, R.L.; Vadlani, P.V. Nutritional enhancement of soy meal via Aspergillus oryzae solid-state fermentation. Cereal Chem. 2013, 90, 529-534. [CrossRef]

45. Wang, Y.; Deng, Q.; Song, D.; Wang, W.; Zhou, H.; Wang, L.; Li, A. Effects of fermented cottonseed meal on growth performance, serum biochemical parameters, immune functions, antioxidative abilities, and cecal microflora in broilers. Food Agric. Immunol. 2017, 28, 725-738. [CrossRef]

46. Ravindran, V.; Blair, R. Feed resources for poultry production in Asia and the Pacific. II. Plant protein sources. Worlds Poult. Sci. J. 1992, 48, 205-231. [CrossRef]

47. Yao, K.; Zhang, T.; Wang, H.; Liu, J. Upgrading of by-product from beverage industry through solid-state fermentation with Candida utilis and Bacillus subtilis. Lett. Appl. Microbiol. 2018, 67, 557-563. [CrossRef]

48. Maehara, L.; Pereira, S.C.; Silva, A.J.; Farinas, C.S. One-pot strategy for on-site enzyme production, biomass hydrolysis, and ethanol production using the whole solid-state fermentation medium of mixed filamentous fungi. Biotechnol. Prog. 2018, 34, 671-680. [CrossRef]

49. Wang, X.; Jin, Q.; Wang, T.; Huang, J.; Xia, Y.; Yao, L.; Wang, X. Screening of glucosinolate-degrading strains and its application in improving the quality of rapeseed meal. Ann. Microbiol. 2012, 62, 1013-1020. [CrossRef]

50. Shi, H.; Su, B.; Chen, X.; Pian, R. Solid state fermentation of Moringa oleifera leaf meal by mixed strains for the protein enrichment and the improvement of nutritional value. PeerJ 2020, 8, e10358. [CrossRef] 